\title{
Analisis Kemampuan Berpikir Kritis Mahasiswa Dalam Menyelesaikan Permasalahan Bilangan Bulat Berbasis Media Realistik
}

\author{
Indri Anugraheni \\ indri.anugraheni@uksw.edu \\ Pendidikan Guru Sekolah Dasar FKIP Universitas Kristen Satya Wacana
} The Analysis Of Student's Critical Thinking Ability In Completing The Problem Of Integer Numbers
Using Realistic Media

\begin{abstract}
The purpose of this study is to describe the ability of college students to think critically in solving integer problems using realistic media. This research is a qualitative descriptive study. The research subjects were 47 elementary school student teachers of FKIP Satya Wacana Christian University, who took realistic mathematics courses. The data collection techniques in this study were tests of college students' critical thinking skills in groups. Critical thinking test results are analyzed by describing college students' thinking abilities. The results of the study note that: the students are able to analyze, evaluate and create operations of addition and subtraction of integers by $24.26 \%$; the students are able to analyze, evaluate but still unable to create problem solving with realistic mathematics media by $34.56 \%$; the students are able to analyze but have not been able to evaluate and accelerate problem solving to a maximum of $13.97 \%$; the students have not been in maximum ability in analyzing mathematical problems and have not been able to evaluate and create problem solving by $27.21 \%$.
\end{abstract}

Keywords: Critical Thinking Ability, Integer Problems, Mathematics Realistic Media

Article Info

Received date: 12 September 2019 Revised date: 23 September 2019 Accepted date: 23 September 2019

\section{PENDAHULUAN}

Perkembangan ilmu dan teknologi saat ini berlangsung sangat sehingga memberikan tantangan kepada setiap individu. Setiap individu dituntut untuk terus mampu belajar menyesuaikan diri dengan perkembangan teknologi. Oleh karena itu diperlukan individu yang berkualitas sehingga mampu meningkatkan sumber daya manusia. Salah satu usaha yang dilakukan dalam meningkatkan kualitas sumber daya manusia melalui bidang Pendidikan.

Perguruan tinggi mempunyai tantangan untuk menghasilkan sumber daya manusia yang berkualitas. Kegiatan perkuliahan diharapkan mampu menumbuhkan dan mengembangkan kemampuan hard skill dan soft skill mahasiswa. Kenyataan di lapangan, mahasiswa hanya memiliki kemampuan hard skill dimana mahasiswa hanya diberikan materi, teori, rumus. Berpikir kritis merupakan salah satu indikator dari soft skill belum dimiliki mahasiswa. Sejalan dengan Farkhiyah (2014: 96) salah satu yang termasuk soft skill berupa kemampuan berpikir kritis dan kemampuan dalam pemecahan masalah.

Matematika merupakan mata kuliah wajib yang diajarkan diperguruan tinggi. Tujuan pembelajaran matematika baik di tingkat dasar maupun di perguruan tinggi adalah membekali mereka dengan kemampuan berpikir logis, kritis, dan kreatif dalam menyelesaikan permasalahan kehidupan sehari-hari. Sejalan dengan Amir (2015: 132) matematika sebagai sarana untuk menumbuhkan kemampuan berpikir logis, analitis, sistematis, kritis dan kreatif mengikuti perkembangan psikologi masing-masing siswa.

Kemampuan berpikir kritis masing-masing mahasiswa berbeda-beda, hal ini dipengaruhi oleh intensitas latihan yang dilakukan mahasiswa. Kenyataan dalam perkuliahan matematika, mahasiswa masih kesulitan dalam mengembangkan kemampuan berpikir kritis. Hal ini dikarenakan masih kurang latihan yang maksimal dalam menyelesaikan permasalahan matematika. Mahasiswa hanya menghafal teori atau rumus matematika.

Berpikir kritis merupakan kemampuan yang sangat penting dikembangkan bagi mahasiswa karena berpikir kritis merupakan suatu aktivitas yang dilakukan dan dikembangkan secara alami. 
Perkuliahan matematika diharapkan melatih mahasiswa untuk melakukan aktivitas berpikir kritis yang mampu membantu mahasiswa dalam menganalisis, mengevaluasi serta menyelesaikan pemecahan masalah matematika. Kemampuan berpikir kritis dapat melatih seseorang untuk melakukan (doing math) pembelajaran matematika (Zetriuslita, Z., Ariawan, R., \& Nufus, H; 2016: 58).

Mahasiswa pendidikan guru sekolah dasar (PGSD) wajib mengambil mata kuliah matematika. Sebagai calon guru sekolah dasar, mahasiwa diharapkan mampu berpikir kritis dalam menyelesikan permasalahan matematika. Oleh karena itu, sejak menempuh pendidikan di perguruan tinggi, mahasiswa dilatih untuk mengembangkan kemampuan berpikir kritis. Tujuan dari perkuliahan matematika realistik adalah mahasiswa diharapkan dapat menyelesaikan permasalahan matematika dengan menggunakan media realistik.

Materi matematika di sekolah dasar yang perlu dikuasai mahasiswa sebagai calon guru sekolah dasar adalah materi bilangan, geometri dan statistika. Materi bilangan banyak dibahas mulai dari kelas bawah hingga kelas atas. Salah satu bilangan yang perlu dikuasi mahasiswa adalah bilangan bulat. Bilangan bulat adalah bilangan yang terdiri dari bilangan positif, bilangan nol dan bilangan negatif. Tujuan dari penelitian ini adalah menganalisis kemampuan berpikir kritis mahasiswa dalam menyelesaikan permasalahan bilangan bulat dengan media berbasis matematika realistik.

\section{KAJIAN PUSTAKA}

Keterampilan berpikir kritis merupakan salah satu tujuan yang wajib dimiliki mahasiswa dalam perkuliahan. Keterampilan berpikir masing-masing mahaisswa berbeda-beda. Azizah, dkk (2018: 62) menyatakan bahwa berpikir kritis adalah proses kognitif peserta didik dalam menganalisis secara sistematis dan spesifik permasalahan yang dihadapi, mampu membedakan mengidentifikasi dan mengkaji informasi guna merencanakan strategi pemecahan masalah.

Rahmawati (2013: 20) menjelaskan berpikir kritis itu sendiri merupakan proses menganalisis atau mengevaluasi informasi dari suatu masalah berdasarkan pemikiran pemikiaran yang logis untuk menentukan keputusan. Stobaugh (2013: 2) menyebutkan bahwa berpikir kritis adalah berpikir yang reflektif secara mendalam dalam memecahkan masalah dan pengambilan keputusan untuk dapat menganalisis situasi, mengevaluasi argumen, serta mampu menarik kesimpulan yang benar. Berpikir kritis adalah suatu proses dimana mahasiswa mampu menganalisis, mengevaluasi pengetahuan yang diterima siswa selama proses pembelajaran (Anugrahana, 2018: 143).

Berdasarkan beberapa pendapat diatas maka dapat disimpulkan berpikir kritis adalah kemampuan mahasiwa dalam proses berpikir yang menganalisis, menghubungkan, menganalisis serta mengkreasikan semua aspek dalam suatu situasi atau suatu permasalahan yang diberikan. Mahasiswa mampu berpikir kritis jika mahasiswa mampu menyimpulkan informasi yang diketahui, mengunakan informasi yang diketahui untuk memecahkan permasalahan, dan mahasiswa mampu mencari sumbersumber informasi dalam menyelesaikan masalah. Hal ini sesuai dengan pendapat yang dikemukakan Ennis (Cahyono: 51) yang dapat disimpulkan bahwa ada hubungan antara berpikir kritis dengan cara menyelesaikan masalah.

Widodo (2015: 52) menyebutkan Pemecahan masalah dalam matematika adalah suatu aktivitas untuk mencari penyelesaian dari masalah matematika yang dihadapi dengan menggunakan semua pengetahuan matematika yang dimiliki oleh peserta didik. Peserta didik mengali kembali informasi yang dimiliki dan mengabungkannya dengan informasi yang baru sehingga mampu menyelesaikan permasalahan.

Menurut Krulik dan Rudnick (1995: 4) mendefinisikan pemecahan masalah adalah suatu cara yang dilakukan seseorang dengan menggunakan pengetahuan, ketrampilan, dan pemahaman untuk memenuhi tuntutan dari situasi yang tidak rutin. Tokoh pemecahan masalah, Polya (1971: 17) menyatakan bahwa pemecahan masalah adalah kemampuan memahami masalah, merencanakan penyelesaian, menyelesaikan permasalahan seduai dengan rencana yang dirancang, dan melakukan pengecekan kembali terhadap semua langkah penyelesaian. Berdasarkan beberapa pendapat tersebut maka pemecahan masalah diartikan sebagai proses usaha yang dilakukan individu(mahasiswa) dalam menyelesaikan permasalahan. Proses usaha yang dilakukan dengan memahami, merencanakan, menyelesaikan dan menari kesimpulan dari permasalahan tersebut. Pemecahan masalah tidak hanya menerapkan pengetahuan dan kaidah yang telah dimiliki tetapi juga mampu menemukan konsep dan kaidah dalam proses berpikir. 
Pembelajaran matematika realistik pada dasarnya adalah pemanfaatan realitas dan lingkungan peserta didik untuk memperlancar proses pembelajaran matematika sehingga tujuan pembelajaran matematika lebih baik dari sebelumnya (Sosiawati, 2011: 81). Pembelajaran matematika artinya dalam kegiatan pembelajaran guru bersama siswa menggunakan media realistik. Media pembelajaran digunakan guru dalam kegitan pembelajaran. Media merupakan alat bantu yang digunakan dosen/guru sebagai pentara dalam menyampaikan materi kepada mahasiswa/siswa. Banyak media pembelajaran yang dapat digunakan dalam kegiatan pembelajaran. Salah satu media yang dapat digunakan adalah media realistik.

Bilangan merupakan salah satu materi yang wajib dikuasai mahasiswa calon guru sekolah dasar. Bilangan bulat merupakan materi yang wajib dikuasai oleh mahasiswa sebagai calon guru. Oleh karena itu sebagai calon guru, mahasiswa diharapkan dapat menguasai materi bilangan bulat. Banyak media realistik yang dapat digunakan oleh mahasiswa dalam mengajarkan bilangan bulat. Salah satu media realistik yang dapat digunakan mahasiswa dalam mengajarkan konsep bilangan bulat adalah media kancing baju. Mahasiswa diberikan permasalahan bilangan bulat, kemudian mahasiswa diminta mencoba operasi hitung penjumlahan bilangan bulat dengan media kancing baju. Setelah mencoba, mahasiswa menuliskan dan menjelaskan operasi hitung bilangan bulat dengan menggunakan media realistik yaitu kancing baju.

\section{METODE PENELITIAN}

Jenis penelitian ini adalah penelitian deskriptif. Tujuan dari penelitian ini adalah mendeskripsikan keteraampilan berpikir kritis mahasiswa. Subjek penelitian ini adalah mahasiswa pendidikan guru sekolah dasar yang mengambil mata kuliah matematika realistik berjumlah 47 mahasiswa yang terdiri dari mahasiswa Angkatan 2016 kelas A dan kelas B. Masing-masing dibagi dalam kelompok yang terdiri dari 2-3 mahasiswa. Teknik pengumpulan data dalam penelitian ini adalah dengan tes berpikir kritis. Tes yang diberikan berkaitan dengan permasalahan bilangan bulat. Permasalahan bilangan bulat terdiri dari 8 soal yang terdiri dari 4 soal operasi hitung penjumlahan bilangan bulat dan 4 soal operasi hitung pengurangan bilangan bulat. Indikator tes yang diberikan kepada mahasiswa mengacu pada taksonomi Bloom ranah kognitif yaitu: C4 (menganalisis), C5 (mengevaluasi), dan C6 (mencipta/mengkreasi). Tes dianalisis dengan cara mencari presentasi dari masing-masing soal yang diberikan. Untuk melihat kemampuan berpikir mahasiswa, peneliti menganalisis aktivitas mahasiswa melalui hasil penyelesaian permaslahan bilangan bulat.

\section{HASIL PENELITIAN DAN PEMBAHASAN}

Media realistik yang digunakan dalam perkuliahan matematika realistik adalah media realistik yaitu kancing baju. Mahasiswa membawa dua kancing baju dengan warna yang berbeda yaitu warna merah dan warna kuning. Kancing warna merah mewakili bilangan bulat positif dan kancing warna kuning mewakili bilangan bulat negatif. Masing-masing kelompok memiliki 30 kancing baju berwarna merah dan 30 kancing berwarna kuning. Ada 8 permasalahan yang diberikan kepada mahasiswa terkait operasi penjumlahan dan pengurangan bilangan bulat. Kemudian mahasiswa diminta untuk menyelesaikan operasi hitung penjumlahan dan pengurangan bilangan bulat dengan media realistik yaitu kancing baju. Mahasiswa mencoba menganalisis penyelesaian dari permasalahan bilangan bulat tersebut. Setelah mampu menganalisis, mahasiswa mampu mengevaluasi dari penyelesaian tersebut. Apakah sesudah sesuai dengan konsep operasi hitung bilangan bulat. Setelah mampu menganalisis dan mengevaluasi, mahasiswa mampu membuat penyelesaian permasalahan bilangan bulat dengan menggunakan gambar.

Berikut adalah hasil analisis kemampuan berpikir kritis pada bilangan bulat dengan menggunakan media realistik. 
Tabel 1. Hasil analisis berpikir kritis mahasiswa

\begin{tabular}{|c|c|c|c|c|c|c|}
\hline \multirow[t]{2}{*}{ Permasalahan } & \multicolumn{5}{|c|}{ Presentase Skor Penilaian (\%) } & \multirow[t]{2}{*}{$\begin{array}{c}\text { Jumlah } \\
(\%)\end{array}$} \\
\hline & 5 & 4 & 3 & 2 & 1 & \\
\hline \multicolumn{7}{|l|}{ Penjumlahan } \\
\hline $\begin{array}{l}\text { Penjumlahan bilangan positif }(+) \text { dengan bilangan } \\
\text { positif }(+)\end{array}$ & 88,24 & 11,76 & 0,00 & 0,00 & 0,00 & 100 \\
\hline $\begin{array}{l}\text { Penjumlahan bilangan positif (+) dengan bilangan } \\
\text { negatif }(-)\end{array}$ & 5,88 & 82,35 & 11,76 & 0,00 & 0,00 & 100 \\
\hline $\begin{array}{l}\text { Penjumlahan Bilangan negatif (-) dan bilangan positif } \\
(+) \text {. }\end{array}$ & 0,00 & 76,47 & 17,65 & 5,88 & 0,00 & 100 \\
\hline $\begin{array}{l}\text { Penjumlahan Bilangan negatif (-) dan bilangan } \\
\text { negatif (-) }\end{array}$ & 58,82 & 23,53 & 17,65 & 0,00 & 0,00 & 100 \\
\hline \multicolumn{7}{|l|}{ Pengurangan } \\
\hline $\begin{array}{l}\text { Pengurangan bilangan positif }(+) \text { dengan bilangan } \\
\text { positif }(+)\end{array}$ & 5,88 & 11,76 & 11,76 & 70,59 & 0,00 & 100 \\
\hline $\begin{array}{l}\text { Pengurangan bilangan positif }(+) \text { dengan bilangan } \\
\text { negatif }(-)\end{array}$ & 11,76 & 29,41 & 41,18 & 17,65 & 0,00 & 100 \\
\hline $\begin{array}{l}\text { Pengurangan Bilangan negatif (-) dan bilangan positif } \\
(+)\end{array}$ & 17,65 & 29,41 & 5,88 & 47,06 & 0,00 & 100 \\
\hline $\begin{array}{l}\text { Pengurangan Bilangan negatif (-) dan bilangan } \\
\text { negatif (-) }\end{array}$ & 5,88 & 11,76 & 5,88 & 76,47 & 0,00 & 100 \\
\hline Jumlah & 194,12 & 276,47 & 111,76 & 217,65 & 0,00 & 800 \\
\hline Presentasi (\%) & 24,26 & 34,56 & 13,97 & 27,21 & 0,00 & 100 \\
\hline
\end{tabular}

Berdasarkan table diatas menunjukan hasil analisis keterampilan berpikir kritis mahasiswa Pendidikan guru sekolah dasar.

Permasalahan 1 menunjukkan bahwa hasil berpikir kritis mahasiswa pada penjumlahan dua bilangan bulat positif dengan bilangan bulat positif sebesar $88,24 \%$ artinya mahasiswa mampu menganalisi, mengevaluasi dan mengkreasi dengan mengunakan media realistik. Sedangkan 11,76\% mahasiswa hanya mampu berpikir kritis sampai tahap menganalisis permasalahan dan mengevaluasi. Tahap menganalisis pada permasalahan operasi hitung dua bilangan penjumlahan bilangan bulat positif adalah tahap dimana mahasiswa mampu membedakan tanda bilangan (bilangan positif atau bilangan negatif) dan tanda operasi hitung. Berikut adalah hasil berpikir kritis mahasiswa pada materi operasi hitung penjumlahan dua bilangan bulat positif:

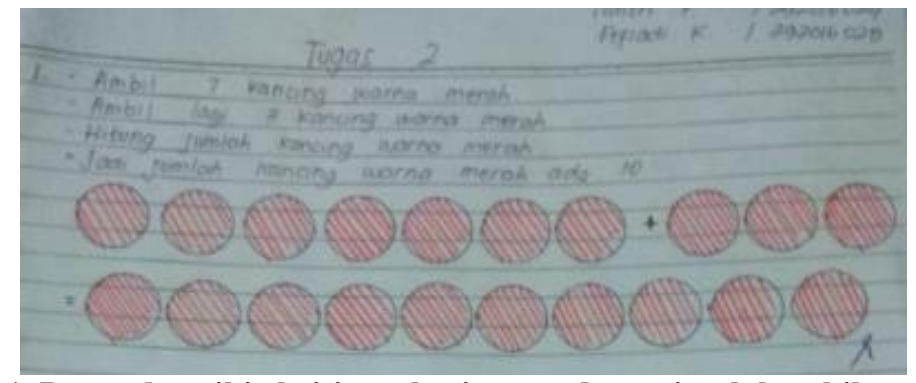

\section{Gambar 1. Proses berpikir kritis mahasiswa pada penjumlahan bilangan positif}

Permasalahan 2 menunjukkan bahawa hasil berpikir kritis mahasiswa pada penjumlahan bilangan bulat positif dengan bilangan bulat negatif sebesar $82,35 \%$ artinya mahasiswa mampu menganalisis, mengevaluasi tetapi belum mampu mengkreasi jawaban dengan media realistik. Tahap menganalisis artinya mahasiswa mampu membedakan tanda operasi hitung dengan tanda bilangan. Jika tanda bilangan maka mahasiswa mengambil sesuai tanda bilangan tersebut. Jika tanda bilanganya npositif maka mahasiswa mengambil kancing berwarna merah, jika tanda bilangan positif maka mahasiswa mengambil kancing berwarna kuning. Jika operasi hitung penjumlahan berarti "menambah". Berikut adalah hasil berpikir kritis mahasiswa pada materi operasi hitung penjumlahan bilangan positif dengan bilangan negatif: 


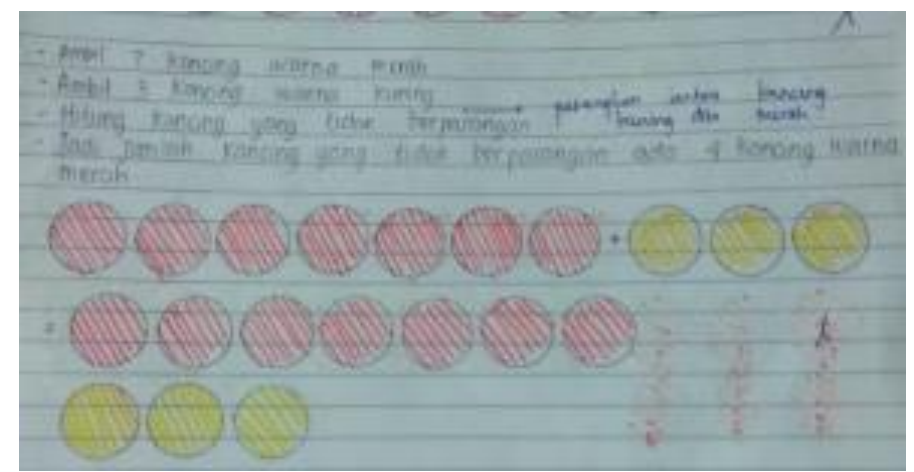

Gambar 2. Proses berpikir kritis mahasiswa pada penjumlahan positif dan bilangan negatif

Permasalahan 3 menunjukkan bahwa hasil berpikir kritis mahasiswa pada operasi penjumlahan bilangan bulat negatif dengan bilangan bulat positif sebersar $76,47 \%$ berada pada kategori mampu menganalisis, mengevaluasi tetapi masih belum bisa mengkreasi. Pada tahap menganalisis, mahasiswa mampu membedakan antara penggunaan tanda bilangan negatif dengan tanda operasi hitung pengurangan pada bilangan bulat. Berikut adalah hasil berpikir kritis mahasiswa pada materi operasi hitung penjumlahan bilangan negatif dengan bilangan positif:

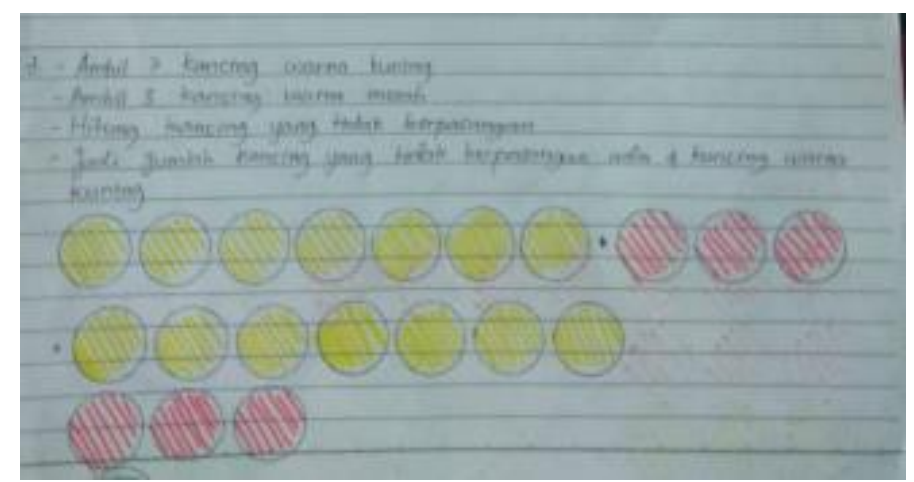

\section{Gambar 3. Proses berpikir kritis mahasiswa pada penjumlahan bilangan negatif} dan bilangan positif

Permasalahan 4 menunjukkan bahwa hasil berpikir kritis mahasiswa pada operasi penjumlahan bilangan bulat negatif dengan bilangan bulat negatif menunjukan bahwa 58,82\% mahasiswa mampu menganalsis, mengevaluasi dan mengkreasi permasalahan dengan menggunakan media realistik. Berikut adalah hasil berpikir kritis mahasiswa pada materi operasi hitung penjumlahan bilangan bulat negatif dengan bilangan bulat negatif.

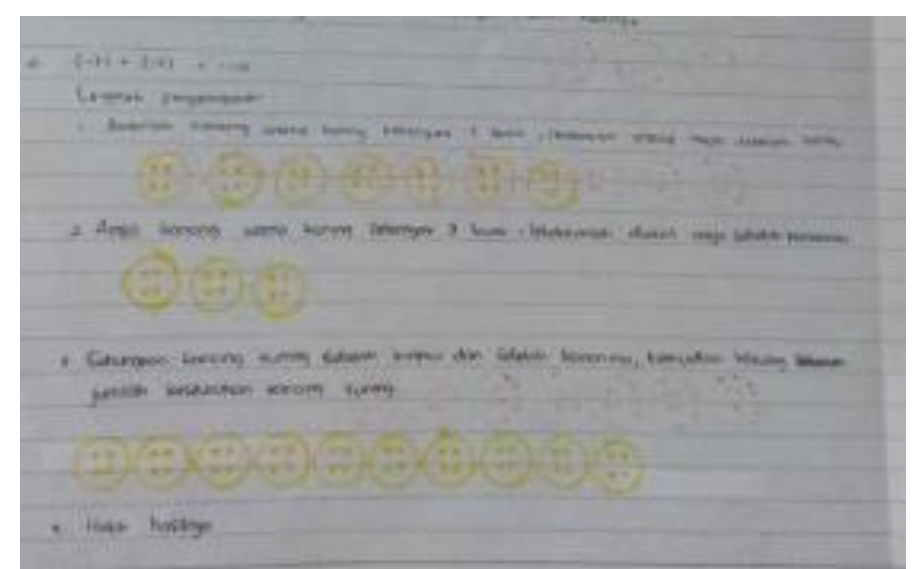

Gambar 4. Proses berpikir kritis mahasiswa pada penjumlahan dua bilangan negatif 
Permasalahan 5 menunjukkan bahwa hasil berpikir kritis mahasiswa pada operasi pengurangan bilangan bulat positif dengan bilangan bulat positif menunjukkan bahwa 70,59\% mahasiswa hanya mampu menganalisis soal tetapi kurang tepat. Mahasiswa belum mampu mengevaluasi dan mengkreasi permasalahan bilangan bulat. Berikut adalah hasil operasi hitung pengurangan bilangan bulat positif dengan bilangan bulat positif:

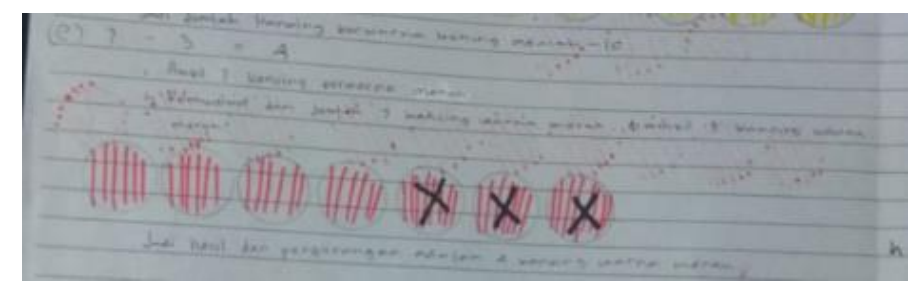

Gambar 5. Proses berpikir kritis mahasiswa pada pengurangan dua bilangan positif

Permasalahan 6 menunjukkan bahwa hasil berpikir kritis mahasiswa pada operasi pengurangan bilangan bulat positif dengan bilangan bulat negatif menunjukkan bahwa 41,18 mahasiswa mampu menganalisis permasalahan dengan benar tetapi masih belum mampu mengevauasi dan mengkreasi permasalahan dengan media realistik. Berikut adalah hasil operasi hitung pengurangan bilangan bulat positif dengan bilangan bulat negatif:

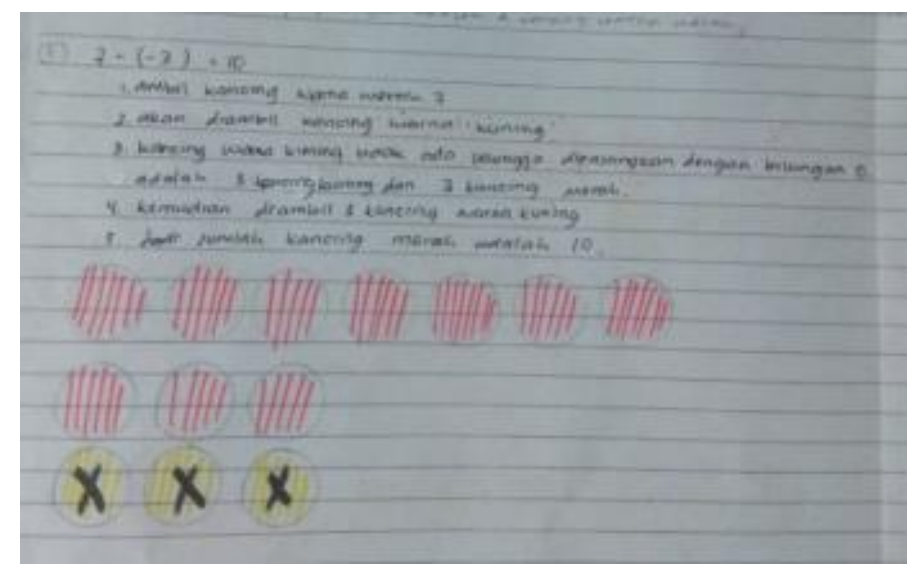

Gambar 6. Proses berpikir kritis mahasiswa pada pengurangan bilangan positif dan negatif

Permasalahan 7 menunjukkan bahwa hasil berpikir kritis mahasiswa pada operasi pengurangan bilangan bulat negatif dengan bilangan bulat positif menunjukan bahwa 47,06\% mahasiswa hanya mampu menganalisis soal tetapi kurang tepat dan mahasiswa belum mampu mengevaluasi dan mengkreasi permasalahan bilangan bulat. Berikut adalah hasil operasi hitung pengurangan bilangan bulat negatif dengan bilangan bulat positif:

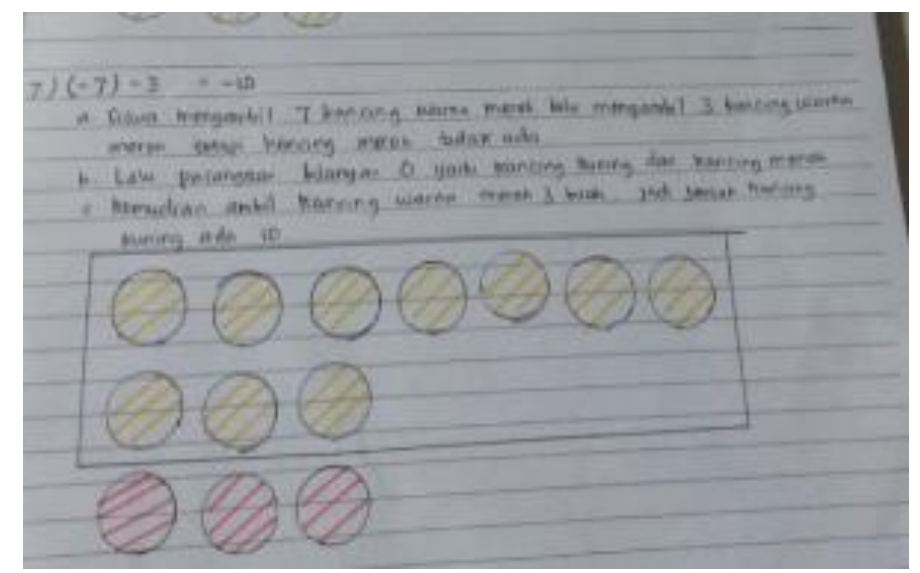

Gambar 7. Proses berpikir kritis mahasiswa pada pengurangan bilangan negatif dan bilangan positif 
Permasalahan 8 menunjukkan bahwa hasil berpikir kritis mahasiswa pengurangan bilangan bulat negatif dengan bilangan bulat negatif sebesar $76,47 \%$ mahasiswa hanya mampu menganalisis permasalahan tetapi masih kurang tepat. Mahasiswa belum mampu mengevaluasi dan mengkreasi permasalahan bilangan bulat. Berikut adalah hasil operasi hitung pengurangan bilangan bulat negatif dengan pengurangan bilangan buat negatif:

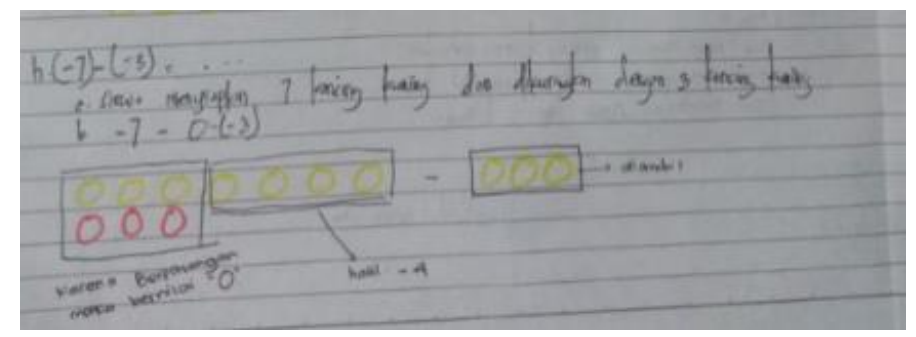

\section{Gambar 8. Proses berpikir kritis mahasiswa pada pengurangan dua bilangan negatif}

Hasil penelitian menujukkan kemampuan berpikir kritis pada operasi hitung penjumlahan dan pengurangan bilangan bulat. Pada tahap menganalisis penjumlahan bilangan bulat, mahasiswa mampu menganalisis operasi hitung penjumlahan bilangan bulat dengan bilangan bulat, penjumlahan bilangan bulat dengan bilangan negatif, penjumlahan bilangan negatif dengan bilangan bulat positif, penjumlahan bilangan bulat negatif dengan bilangan bilangan negatif. Mahasiswa mampu menganalisis dengan menentukan media ralistik yang digunakan. Mahasiswa menentukan bilangan positif diwakili media kancing berwarna merah dan bilangan negatif diwakili kancing berwarna kuning.

Hasil penelitian berpikir kritis mahasiswa dalam menyelesaikan permasalahan bilangan bulat berbasis media realisik adalah mahasiswa mampu menganalisis, menevaluasi dan mengkreasikan operasi hitung penjumlahan dan pengurangan bilangan bulat sebesar 24,26\%; mahasiswa mampu menganalisis, mengevaluasi tetapi masih belum mampu mengkreasikan penyelesaian masalah dengan media matematika realistik sebesar 34,56\%; mahasiswa mampu menganalisis tetapi belum mampu mengevaluasi dan mengkerasi penyelesaian masalah secara maksimal sebesar 13,97\%; mahasiswa belum maksimal dalam menganalisis permasalahan matematika dan mahasiswa belum mampu mengevaluasi dan mengkreasi penyelesaian masalah sebesar $27,21 \%$. Hasil penelitian ini sejalan dengan penelitian Zetriuslita, dkk (2016: 64) tentang analisis kemampuan berpikir matematis mahasiswa dalam menyelesaikan soal uraian kalkulus integral. Mahasiswa berada pada level kemampuan matematis dan kemampuan menggeneralisasikan tetapi mahasiswa belum memiliki kemampuan yang maksimal dalam menganalisis. Penelitian yang dilakukan Anugrahana (2018: 154) mahasiswa melakukan proses keterampilan tingkat tinggi dalam menganalisis, mengevaluasi dan mengkreasi. Mahasiswa melakukan pemeriksaan, dugaanm percobaan. Penelitian yang dilakukan oleh Setyaningtyas, E. W. (2019: 120) mengembangkan keterampilan berpikir kritis dan kreatif mahasiswa. Penilaian berpikir kritis mengarah pada kemampuan membandingkan, mengklarifikasi, menilai, memilih dan memodifikasi.

\section{SIMPULAN DAN SARAN}

Simpulan dari penelitian ini adalah mahasiswa mampu berpikir kritis dalam menyelesaikan permasalahan bilangan bulat. Indikator berpikir kritis terdiri dari menganalisis, mengevakuasi dan mengkreasi. Mahasiswa mampu melakukan analisis permasalahan bilangan bulat dengan menggunakan media matemaika realistik. Mahasiswa belum maksimal dalam melakukan tahap evaluasi dan mengkreasi permasalahan bilangan bulat. Permasalahan bilangan bulat merupakan salah satu permasalahan matematika. Dosen/pendidik mempunyai tanggung jawab untuk melatih mahasiswa melakukan kegiatan pemecahan masalah matematika.

Oleh karena itu diharapkan dalam penelitian-penelitian selanjutnya dosen/pendidik lebih sering melatih mahasiswa untuk melakukan pemecahan masalah terutama pada tahap mengevaluasi dan mengkerasi. Permasalahan yang diberikan kepada mahasiswa/peserta didik tidak hanya permasalahan pada memahami, mengetahui, mengaplikasikan saja tetapi mahasiswa/peseta didik perlu diberikan permasalahan yang menuntut mereka berpikir kritis. Permasalah kognitif pada ranah menganalisis, 
menevaluasi, mengkreasi sehingga mereka mampu menghadapi perkembangan teknologi yang membutuhkan kemampuan berpikir kritis.

\section{DAFTAR PUSTAKA}

Amir, M. F. (2017). Analisis Kesalahan Mahasiswa PGSD Universitas Muhammadiyah Sidoarjo Dalam Menyelesaikan Soal Pertidaksamaan Linier. JURNAL EDUKASI: KAJIAN ILMU PENDIDIKAN., 1(2), 131-146.

Anugrahana, A. (2018). Tinjauan Deskriptif Penerapan Higher Order Thinking dan Problem-Based Learning Pada Mata Kuliah Geometri Berdasarkan Kemampuan Matematika Mahasiswa. Scholaria: Jurnal Pendidikan Dan Kebudayaan, 8(2), 142-156.

Azizah, M., Sulianto, J., \& Cintang, N. (2018). Analisis Keterampilan Berpikir Kritis Siswa Sekolah Dasar pada Pembelajaran Matematika Kurikulum 2013. Jurnal Penelitian Pendidikan, 35(1), 61-70.

Cahyono, B. (2017). Analisis Ketrampilan Berfikir Kritis Dalam Memecahkan Masalah Ditinjau Perbedaan Gender. AKSIOMA: Jurnal Matematika dan Pendidikan Matematika, 8(1), 50-64.

Potensi Metode 1: 4: P: C: R untuk Mengembangkan Keterampilan Berpikir Kritis dan Kreatif. Scholaria: Jurnal Pendidikan dan Kebudayaan, 9(2), 111-121.

Fakhriyah, F. (2014). Penerapan Problem Based Learning dalam Upaya Mengembangkan Kemampuan Berpikir Kritis Mahasiswa. Jurnal Pendidikan IPA Indonesia, 3(1).

Krulik, Stephen \& Rudnick, Jesse A. (1995). The New Sourcebook for Teaching Reasoning and Problem Solving in Elementary School. Needham Heights: Allyn \& Bacon

Polya, G. (1973). How To Solve It, Second Edition, New Yersey, Princeton University Press.

Rakhmawati, Y; Chamdani M; Chrysti S K. (2013). Penerapan Model PBL dalam Peningkatan Berpikir Kritis IPA Siswa Kelas V SD. Kalam Cendekia PGSD Kebumen, 3(2).

Setyaningtyas, E. W. (2019). Potensi Metode 1: 4: P: C: R untuk Mengembangkan Keterampilan Berpikir Kritis dan Kreatif. Scholaria: Jurnal Pendidikan dan Kebudayaan, 9(2), 111121.Stobaugh, R. (2013). Assessing critical thinking in middle and high schools: Meeting the Common Core. Routledge.

Soviawati, E. (2011). Pendekatan matematika realistik (pmr) untuk meningkatkan kemampuan berfikir siswa di tingkat sekolah dasar. Jurnal Edisi Khusus, 2(2), 79-85.

Widodo, S. A., \& Sujadi, A. A. (2015). Analisis kesalahan mahasiswa dalam memecahkan masalah trigonometri. SOSIOHUMANIORA: Jurnal Ilmiah Ilmu Sosial dan Humaniora, 1(1).

Zetriuslita, Z., Ariawan, R., \& Nufus, H. (2016). Analisis kemampuan berpikir kritis matematis mahasiswa dalam menyelesaikan soal uraian kalkulus integral berdasarkan level kemampuan mahasiswa. Infinity Journal, 5(1), 56-66. 